\title{
A Study of University Counselors' Ideological and Political Education Discourse Innovation from the Perspective of New Media*
}

\author{
Hongxia Yan \\ Southeast University Chengxian College \\ Nanjing, China
}

\begin{abstract}
In the era with the rapid development of new media, the discourse paradigm of traditional ideological and political education can no longer meet the real needs of contemporary university students. The propagation characteristics of new media such as "space-free, interaction, and dialogue" provide a new context for discourse content, discourse relations, and discourse concepts in ideological and political education in universities. The ideological and political education in colleges and universities fell into the discourse difficulties. On the one hand, in the context of new media, the discourse platform is more diverse, the content of discourse is more abundant, and the discourse mode is more diverse; on the other hand, the dissemination of information is more disorderly, mainstream values have been affected, and the ideological and political discourse of universities has become weaker. To solve the discourse dilemma, first we must start from the outside to change the pattern of discourse, strengthen the background support of the discourse, and eliminate discourse hegemony; second, we must proceed from the inside to improve discourse literacy, explore discourse resources, and improve the art of discourse.
\end{abstract}

Keywords—self-media; college counselors; the right to speak

\section{INTRODUCTION}

It is the foundation of the socialist universities with Chinese characteristics under the leadership of the Chinese Communist Party to set up morals and educate people is the, and it is the only way to promote the healthy development of higher education by strengthening and improving ideological and political work in universities. The development of modern universities is accompanied by many characteristics such as globalization, diversification, information, and intelligence. In particular, the rapid development of new media has made ideological and political work more complex. The personalization tendency of work objects is more obvious and it is a problem that universities need to solve urgently.

*Project Source: Special Project for 2016 Counselors' Work Association of Jiangsu Province (Project No.: 16YHLX044); Southeast University Cheng Xian College Youth Fund "Research on the Assessment and Incentive Mechanism Innovation of Independent College Counsellors" (Project number Y0008)2017 Jiangsu University Philosophy and Social Science Research Project, Project Title: Research on the Weakening and Reshaping of University Counselor's Discourse Power under the View of Media, Project Number: 2017SJBFDY072.
In December 2016, General Secretary Xi Jinping emphasized at the National College Ideological and Political Work Conference that "We must firmly grasp the party's leadership in the work of universities and the dominance of ideological and political work". As the backbone of the ideological and political work of colleges and universities, the counselors must grasp the right to speak and firmly hold onto the university's ideological positions. It is an era issue that universities and college ideological and political educators need to solve urgently about how college counselors reshape the right of speech, improve the discourse expression mechanism, turn passive state into initiative one, turn risks into opportunities, break the dilemma of counselors' ideological and political education discourse, and realize discourse paradigm shift in ideology.

\section{THE Position AND Role OF COUNSELORS AND THEIR} RIGHT TO SPEAK IN IDEOLOGICAL AND POLITICAL EDUCATION

\section{A. Right to Speak and the Right of Speech in Ideological and Political Education}

Discourse is the ideological and emotional communication between humans. According to Foucault, a French ideologist, discourse is a system of expression power, it is a real social right hidden behind knowledge, reason, and institution. The so-called "right to speak" is the ability to speak and the control of public opinion. The discourse right of ideological and political education is the language system used by counselors following certain language norms and laws to carry out ideological and political work in order to achieve certain goals. It is a comprehensive embodiment of discourse rights, power, and capabilities and has a clear ideology and purpose.

\section{B. Manifestations of Counselors' Right to Speak}

There are four manifestations of counselors' right of speech:

The first is political discourse. As the main force of ideological and political education in colleges and universities and as a political guide for college students, the counselor implements the party's guidelines and policies, and educates college students on world outlook, outlook on life, and values. These discourses which firm students' ideals and beliefs all 
come from Marxism-Leninism, Mao Zedong Thought, the theoretical system of socialism with Chinese characteristics, and the state's major policies and policies;

The second is discourse of disciplines. As organizers, managers, and implementers of grass-roots in colleges and universities, counselors exercise educational management rights and express and implement discourses about the school rules and regulations, including management about college students' daily lives, disciplines and emergencies of various unexpected events;

The third is advisory discourse. As study mentors, career planners, and psychological counselors, college counselors are responsible for student's management consulting, including learning advice, counseling about all things and psychological counseling etc.;

Fourth, the affective discourse. These discourses are those expressing personal emotions as independents, such as the concern for daily lives of students. The contents are about physiology, psychology, life, and spiritual care that based on respect, trust, care, understanding and encouragement, which building an emotional connection between the counselors and students.

\section{The Orientation and Role of Counselors and Their Right to Speak in Ideological and Political Education}

College counselors are the backbone of college students' ideological and political education. They are the organizers, implementers, and mentors of college students' daily ideological and political education and management. The counselor's right to speak is an important guarantee for his work to proceed smoothly, for the education, management, and service. The counselor's right to speak has obvious professional characteristics. It influences college students' thoughts and behaviors through systems, knowledge, management, etc. It has strong binding force and guiding force and is an important means for carrying out ideological and political education.

\section{The StATUS AND DilemMA OF COLLEGE COUNSElOR DISCOURSE IN THE PERSPECTIVE OF NEWMEDIA}

\section{A. Development Opportunities Brought by New Media to College Counsellors}

1) Provide a new platform to enhance the influence of college counselors' ideological and politicaldiscourse power: The new media has broken through the various limitations of traditional single-transition communication and opened up a broad channel for two-way interactive communication. The carriers such as blogs, Weibo, and forums have expanded the discourse platform of college counselors. It breaks the single form of education based on preaching, creating a "dynamic", "open", and "diversity" discourse environment and providing a new discourse platform for college counselors, which broadens the ways for college counselors to carry out ideological and political work.
The traditional ideological and political education is based on the one-way indoctrination of the counselors and the passive acceptance of the students. From the perspective of the media, the ideological and political education in institutions of higher learning is transformed from individual indoctrination to two-way interaction and communication between teachers and students, which is conducive to understanding students' ideas and improving the effectiveness of ideological and political education. On the media platform, college students are more willing to open their hearts and express their own inner true feelings. The use of self-media platforms to conduct ideological and political education can not only make teachers know students' concerns in a timely manner, but can also achieve a two-way interaction, which is conducive to enhancing the influence of students' ideological and political education.

2) It can expand educational resources and enriched the connotation of college counselors'ideological and political education: With the advent of new media and rapid dissemination of information resources have provided abundant sources for college counselors' ideological and political education, and the latest and hottest topics and cases have enriched the content of the ideological and political education of counselors. In the new environment with media, the counselors update the educational content through the new media platform, use live cases to influence young students, and enhance the appeal and influence of the counselor's discourse. The traditional discourse of ideological and political education is dominated by written information, thus emotional communication between teachers and students is difficult to carry out. In the perspective of new media, the forms of discourse are concise, diverse, and humorous. The information delivered by the new discourse methods such as voice, facial expressions, and pictures is more lively and vivid, and the emotional expression is more direct, which greatly increases the interest and appeal of ideological and political education discourse.

\section{B. Challenges Brought by the New Media to College Counsellors' Ideological and Political Education Discourse}

1) The role of the counselor in "guiding people" weakens, which eliminates the control of theideological and political education discourse: In the traditional ideological and political education work, college counselors play a leading role in the growth of college students, have a certain power of control, and act as a gatekeeper of information. The media's characteristics such as being open, free, interactive have built an equal and inclusive discourse system. On the one hand, the popularization of the Internet has promoted the diversification of education subjects. Undergraduates can freely select information according to their own interests and hobbies and are no longer confined to the instructor's indoctrination. On the other hand, the new information dissemination methods represented by the Internet are sought after by college 
students with the advantages of being instant, interactive, and multi-centered.

The control of the ideological and political education discourse is the key to the effectiveness of the ideological and political work. Once the college counselor loses the control of the discourse, he lacks the ability to "select" and "check" the information. Various ideas and opinions are bound to affect the university students on their concepts of life and values. In the realistic context where information from the we-media is mixed and hard to tell the truth and falsity, college students have abused the right to speak and have even become disseminators of bad information. The role of counselors in "guiding people" has been continuously weakened, and the gradual loss of the coach's discourse control over ideological and political education has caused a certain impact on his discourse power.

2) Diversified sources of information have shaken the dominance of college counselors'ideological and political education discourse: In the traditional ideological and political work of colleges and universities, the counselors undertake the roles of ideological and political education organizers, controllers, dominators, and implementers in practical activities such as education and teaching, student management, etc. They have absolute dominance in the dissemination of information and a higher discourse influence on students. The arrival of the new media era has imperceptibly changed the ideological and political education subjects, objects, mediators, educational processes, and education methods, and has innovated the channels and methods of educating, serving, managing, and guiding students.

The era of new media has promoted the diversification of education subjects and sources of information. Undergraduates have chosen education subjects according to their personal preferences and needs. The dominance of counselors in obtaining information channels among undergraduates has been weakened. In the process of ideological and political education, students gradually assumed a dominant position, which shakes the dominance of college counselors' ideological and political education discourse.

\section{Recent Status and Dilemma in the Weakening of the Voice of University Counsellors' Ideological and Political Education in the View of New Media}

1) The complexity of therole orientation and the confusion of context switching lead to theweakening of the counselor's discourse: The "Provisions on the Construction of Counsellors for General Higher Education Institutions" (hereinafter referred to as the "Regulations") of the Ministry of Education defines eight job responsibilities of college counselors. Counsellors are often assumed as educators, managers, servers, psychological counselors, and caring friends. However, in the student's view, the counselor is a combination of clerk, toll collector, fire fighter, baby sitter, security guard, nursing worker, etc. The role positioning is complex and changeable, and the discourse context keeps switching.

Counselors use political discourse to do ideological work and carry out education on world outlook, outlook on life, and values; use regulatory discourse to do management work to accurately communicate and implement school rules and regulations; use emotional language to chat with students and talk about the world. The counselor's discourse context changes frequently. If the measures are misunderstood and the roles are confused, the authority of the discourse will be greatly reduced, leading to the weakening of the ideological and political education discourse of the counselors.

2) The ambiguity of the professionalism of the counselor and the lack of professional identification make it difficult to establish the power of the discourse: College counselors have the dual status of teachers and management cadres. However, compared to professional teachers, the counselors lack the advantages of subject knowledge. Some counselors are not majored in ideology or politics, they do not have a strong professional background or are not equipped with academic theories, thus they are in a weak position in academic discourse; compared to management cadres, college counselors are not leaders but grass-roots managers. In administrative discourse systems, counselors are mostly executors. Their right to speak is insufficient.

The professional identity of counselors is also an important factor influencing discourse. The room for promotion of counselors is very small while the pressure of the work is high. They have a weak sense of professional belonging and the position is unstable. The counselors lack enthusiasm and innovation in the work, treat the work with a perfunctory attitude, and hide his discourse in the execution and completion of tasks. As a result, the influence of the ideological and political education discourse is insufficient, and the counselor gradually becomes "Aphasia" in the discourse system in colleges and universities.

3) The theoretical knowledge is insufficient to meet the spiritual needs of young people, which leads to the dispelling of the discourse of counselors: Knowledge is an important source of ideological educator's discourse. The ideological and political education discourse has an influence on students based on the selection, dissemination and distribution of knowledge. College counselors are mostly undergraduates or postgraduates, some of them are not from the specific majors. They are lack of work experience, theoretical reserves, and politic experiences.

Contemporary college students are active in thinking. In today's environment where the information acquisition and the value choices are diverse, counselors are no longer the main source of knowledge acquisition. The new platform represented by new media has become a new space for university students' speech. College counselors' speech is difficult to counter that of the "network leaders" in terms of frequency, authority, quantity, and form. 


\section{The INNOVATION PATH OF COLLEGE COUNSELORS RIGHT TO SPEAK FROM THE PERSPECTIVE OF WE-MEDIA}

College counselors should cater to the actual needs of the new media era, actively adapt to the requirements of the university's ideological and political education discourse rights in the new situation and take the initiative to win the right to speak.

A. Ensure the Role of an Educator and Consciously Assume Themselves as the "Gatekeepers" and "Opinion Leaders" in the Era of We-media

1) Counselors should consciously undertake the role of "gatekeepers": In the process of ideological and political education, the counselor must choose the content of education and education methods. In particular, key points such as ideas, values, and ethics should be checked. In the era of new media, information transition is unimpeded and the quality of information is uneven. It is of the utmost importance to help students to form the correct outlook on life, world outlook and their values. Therefore, college counselors must grasp the requirements of the role of a "gatekeeper".

2) College counselors should consciously become "opinion leaders" to lead the public opinion and seize the right of the discourse: The counselor must first make an authoritative voice to shape a positive image and spread positive energy. Only when college counselors become "opinion leaders" can they master the dominance and guiding power of discourse of ideological and political education. At key moments, when various viewpoints are mixed and interwoven, counselors must take a clear-cut stand and dare to actively speak up. They should play the main melody in the public voices, promote positive energy, improve the ability of students to resist corruption and turmoil, the ability to distinguish right from wrong, and the ability to resist risks.

B. Raise the Theoretical Level, Tap the Discourse Resources, and Enrich the Discourse Content of the Ideological and Political Education of the Counselors

1) College counselors should consciously upgrade their theoretical level, innovate the discourse system, and form an ideological and political education discourse system with Chinese characteristics and positive energy: Adhere to Marxist theory education, advance the latest achievements of Marxist theory into the classroom, teaching materials and the mind; adhere to China's national conditions and socialist theoretical education with Chinese characteristics, strengthen the education of international and domestic situation, and increase "four confidences"; adhere to the Education of Socialist Core Values, integrate and practice the Socialist Core Values into college work and daily Life of college students; adhere to the dissemination of China's excellent traditional culture and advanced socialist culture.

2) College counselors must strive to expand the source of knowledge, enrich the content ofideological and political education, and increase the appeal of words: Counsellors should learn to excavate the discourse resources from the ideology of Marxist classic writers and the essence of Chinese excellent traditional culture. We must learn from the excellent ideological and political education discourse in our party's history and give it specific era characteristics; the counselor must also learn to dig into and transform the political discourse and power discourse, triggering students' inner resonance; counsellors should learn to draw resources from the daily life of college students and the public, and refine the discourse content of ideological and political education.

3) Counsellors should integrate effective resources, absorb language resources in the era of new media, and enrich the forms of discourse: Counsellors should be good at translating and absorbing network hot words, inspire university students' emotional identity and ideological resonance, and improve the power of discourse in ideological and political education. Be concerned about the students' actual study, life, physiology, and psychological appeal, be close to the life and practice of college students, and focus on the hot issues, and give scientific and correct guidance; pay attention to topics appealing to college students, carry out special lectures, and set up platforms to give positive guidance; make use of important historical opportunities, major festivals to organize various forms of educational activities.

\section{Improve Discourse Literacy and Enhance Counselors' Ideological and Political Education Discourse Ability}

1) Strengthen the training of discourse expression skills and enhance the discourse ability: Counsellors should master communication skills, use humorous language to attract students' attention, and use the vivid metaphor to improve students' understanding, explaining the profound truth to the students with plain words. To use euphemistic, implicit, humorous, and humorous language to praise students for their good behavior, and to criticize them for their mistakes, so as to solve embarrassment with humor and replace criticism with relaxed words, which can not only enhance the discourse performance of the counselor but can also help students to form positive personality traits.

2) The instructor should innovate the form of discourse: In line with the basic principles of "popularizing the academic issues, making serious topics (political topics) close to life, making complex issues simple, and assimilating Marxism in China", counselors should use verbatim, vernacular, and comprehensively use text discourse, verbal discourse, online discourse, and practical discourse to carry out interactive and participatory communication. At the same time, they dare to learn from and use the prevailing social discourse and apply it to the ideological and political education discourse.

\section{Counsellors Should Improve Media Literacy and Master New Media Technologies}

1) Set up a we-media platformwith diversities to improve the use of new media technologies: Establish we-media platforms such as the official Weibo and WeChat public 
accounts, through to publish information, carry out democratic voting and psychological counseling, etc., thus forming a discourse influence among students; at the same time, they can join groups such as class QQ groups and WeChat groups to solve problems in time for students. They can also understand the popular online language in students and interact with them in order to expand their influence in the students. Counsellors should master the rules of use of the official platform and chatting groups, be familiar with college students' QQ and WeChat moments, Weibo, forums and other platforms to understand the current hot spots and focus that students know. They should strengthen interactions with students and bring them closer.

2) Create a civilized network environment: Due to the low barriers to the entry of new media platforms, the network environment is relatively complicated and is lack of supervision. College students are active in thinking. When expressing their views on social events, they are prone to add in their personal feelings. With weak legal consciousness and security awareness, they may even give inappropriate speeches. This requires the counselor to strengthen the cyber civilization and safety education, educate students to consciously reject bad information, improve their ability to distinguish between true and false information, and guide students to express their personal views rationally in the online environment.

\section{CONCLUSION}

The arrival of the new media era transformed college students from passive learners into active participants in education, which requires instructors to update their educational concepts, change their modes of thinking, innovate their working methods, make full use of new media platforms to find a point that is correspondent to students' interest and eliminate discourse hegemony in the new media environment.

\section{REFERENCES}

[1] Zeng Qingtao, Hu Shuxiang. The Evolution of Internet We-Media and Its New Requirements for Dissemination of Ideological and Political Education on Internet [J]. Research in Ideological Education. 2016, (3) 曾庆桃胡树祥.网络自媒体演进及其对网络思想政治教育话语传播 的新要求 $[\mathrm{J}]$.思想教育研究.2016,(3)

[2] Zhang Rui. Research on the Weakening and Reshaping of College Teachers' Right to Speak [J]. College Instructors. 2016, (6) 张睿. 高校 辅导员话语权的弱化与重塑研究[J]. 高校辅导员.2016,(6)

[3] Zhao Yuping. The Inherent Logic and Realistic Path of College Counselors' Promotion of Discourse in Ideological and Political Education. Ideological Education Research, 2016, (6) 赵癸萍. 高校辅 导员提升思想政治教育话语权的内在逻辑与现实路径. 思想教育研 究 2016,(6)

[4] Liu Hongda. The Evolution of Internet We-Media and Its New Requirements for Dissemination of Ideological and Political Education on Internet [J]. Journal of Ideological Education. 2017, (5) 刘宏达.网络 自媒体演进及其对网络思想政治教育话语传播的新要求 [J]. 思想教 育研究.2017,(5)

[5] Li Li, Zhang Hui-lai. Three Keys for University Counselors to Control the Discourse Rights of Ideological and Political Education on Internet [J]. Journal of College Counsellors. 2017, (4) 李丽, 张会来. 高校辅导 员掌握网络思政教育话语权的三个关键 [J]. 高校辅导员学刊.2017,(4) 